\title{
Invasion of French Polynesia by the Glassy-Winged Sharpshooter, Homalodisca coagulata (Hemiptera: Cicadellidae): A New Threat to the South Pacific ${ }^{1}$
}

\author{
Fulie Grandgirard, ${ }^{2,3}$ Mark S. Hoddle, ${ }^{4}$ George K. Roderick, ${ }^{5}$ Férôme N. Petit, ${ }^{2}$ Diana Percy, ${ }^{2}$ \\ Rudolph Putoa, ${ }^{6}$ Charles Garnier, ${ }^{6}$ and Neil Davies ${ }^{2}$
}

\begin{abstract}
The glassy-winged sharpshooter, Homalodisca coagulata (Say), is a major pest of agricultural, ornamental, and native plants. It is native to the southeastern United States and northeastern Mexico. Homalodisca coagulata was first recorded in Tahiti (French Polynesia) in 1999. It reproduced and spread rapidly in French Polynesia and is currently found in almost all islands in the Society Islands group (Tahiti, Moorea, Raiatea, Huahine, Bora Bora, Tahaa, Maupiti), in Nuku Hiva in the Marquesas, and in Tubuai and Rurutu in the Australs. Tahiti and Moorea are the most heavily infested islands, where $\mathrm{H}$. coagulata populations have reached densities far exceeding those observed in California (this pest invaded California in the late 1980s) or in its native range. Major factors responsible for high population densities of H. coagulata in French Polynesia are permissive environmental conditions (mild climate and abundant year-round feeding and oviposition substrates), absence of host-specific natural enemies, intoxication of generalist predators that attack nymphal and adult stages, and limited competition for resources. Homalodisca coagulata causes several problems in French Polynesia: dripping excreta from high densities of feeding adults and nymphs affect outdoor recreation under trees and create a social nuisance, attraction of large numbers of flying adults to lights at night and collisions with people are severe annoyances, and large numbers of $H$. coagulata feeding on plants can cause impaired growth. The major concern for French Polynesia is the possibility of this pest acquiring and vectoring the lethal plant bacterium Xylella fastidiosa, which could have a disastrous impact on ornamental, agricultural, and native plants. Surveys are currently under way to detect $X$. fastidiosa in French Polynesia. Presence of large populations of $H$. coagulata in French Polynesia presents a major threat to agriculture and the biodiversity of South Pacific countries because this insect has clearly demonstrated a high invasion potential.
\end{abstract}

\begin{abstract}
${ }^{1}$ Financial support for research on $H$. coagulata was provided by the French Polynesian government (Convention no. 4.0328). Additional support came from the University of California, Berkeley and Riverside; the University of California Division of Agriculture and Natural Resources; the California Department of Food and Agriculture; and the Secretariat of the Pacific Community. This paper is contribution no. 137 of the Richard
\end{abstract}

Pacific Science (2006), vol. 60, no. 4:429-438

(C) 2006 by University of Hawai'i Press

All rights reserved
B. Gump South Pacific Research Station. Manuscript accepted 19 December 2005.

${ }_{2}^{2}$ Richard B. Gump South Pacific Research Station, University of California, Berkeley, BP 244, 98728, Moorea, French Polynesia.

${ }^{3}$ Corresponding author: e-mail: julie@moorea .berkeley.edu.

${ }^{4}$ Department of Entomology, University of California, Riverside, California 92521

${ }^{5}$ Environmental Science, Policy and Management, Division of Insect Biology, University of California, Berkeley, California 94720.

${ }^{6}$ Service du Développement Rural, BP 100, 98713, Papeete, Tahiti, French Polynesia. 


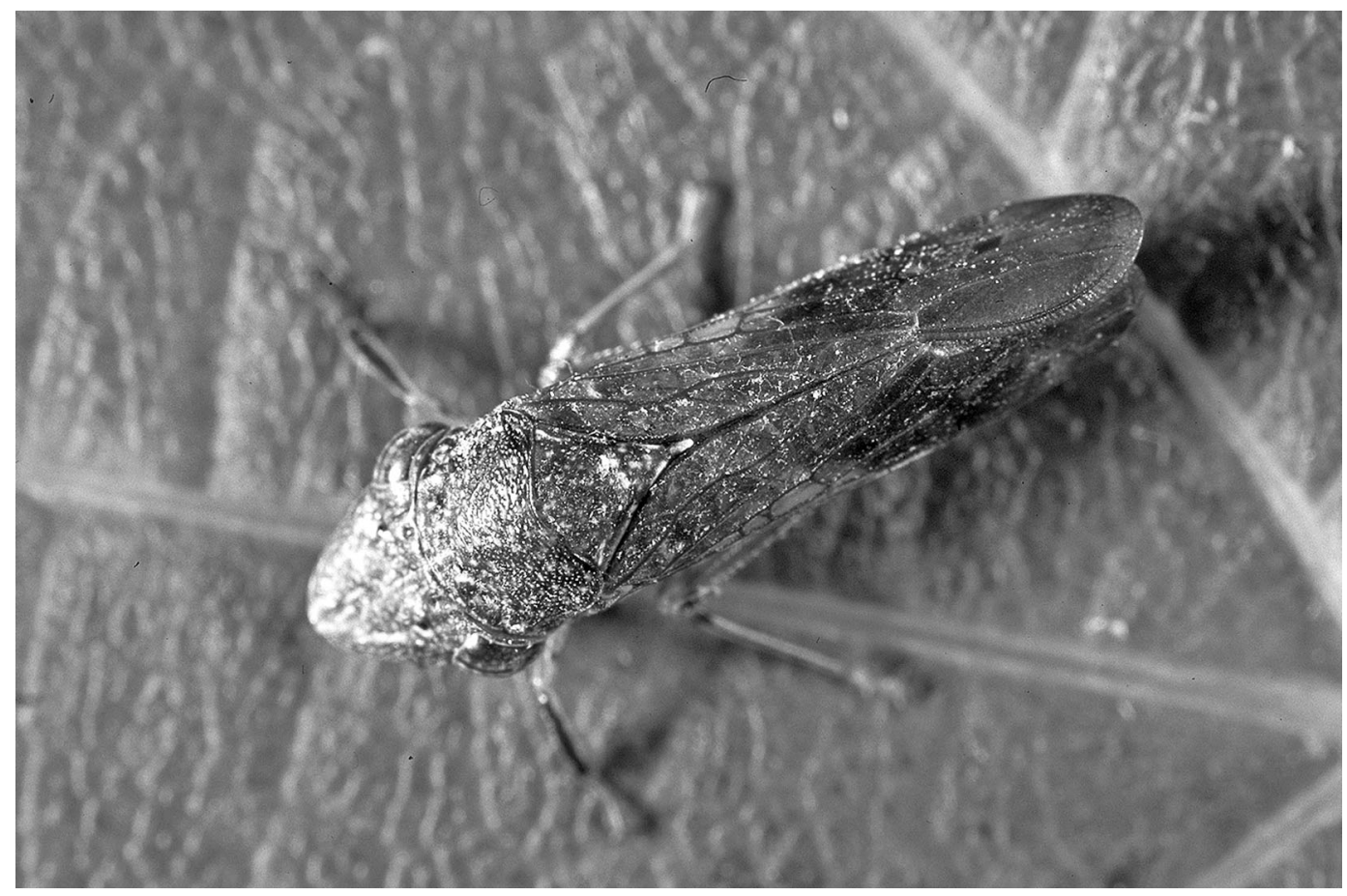

FIgURe 1. The glassy-winged sharpshooter, Homalodisca coagulata (Say). Photo by Jack Kelley Clark, courtesy UC Statewide IPM Program.

The glassy-winged sharpshooter, Homalodisca coagulata (Say) (Figure 1), is native to the southeastern United States and northeastern Mexico (Triapitsyn and Phillips 2000). In the late 1980s this insect invaded California in the United States (Sorensen and Gill 1996), and by the mid-1990s populations in Southern California had become widespread and extremely pestiferous in agricultural and urban areas (Pilkington et al. 2005). Homalodisca coagulata exhibits high invasion potential, having become successfully established in the Pacific islands: French Polynesia in 1999 (Secretariat of the Pacific Community 2002), Hawai'i in 2004 (Hoover 2004), and Easter Island in 2005 (Sandra Ide, 2005, pers. comm.). Climate match modeling suggests that many other areas of the world are highly vulnerable to invasion by $H$. coagulata (Hoddle 2004).

Homalodisca coagulata is xylophagous. $\mathrm{Xy}-$ lem fluids lack defensive secondary chemicals that require detoxification, and this may account for the extreme polyphagy of this insect (Raven 1983). Due to the low nutritional value of xylem, xylophages need to ingest large quantities of fluid. Consequently, H. coagulata can consume up to 100 times its body weight per day (Brodbeck et al. 1993), and copious amounts of watery excreta are produced and continuously discharged as a result of prolific feeding. Females lay eggs within plant tissue on the underside of leaves. Adults and the five nymphal instars can feed on more than 150 plant species in 34 plant families (Hoddle et al. 2003). In its home range and invaded areas, the major threat posed by $H$. coagulata to agricultural crops and ornamental and native plants is its ability to vector a xylem-dwelling bacterium, Xylella fastidiosa (Wells et al. 1987), which causes a variety of lethal scorchlike diseases in susceptible hosts (Hopkins and Purcell 2002). 
INVASION OF TAHITI BY HOMALODISCA COAGULATA

In French Polynesia, H. coagulata was first reported in July 1999 on the windward island of Tahiti in the Society Islands archipelago (Secretariat of the Pacific Community 2002). Nymphs and adults were found on one specimen of Lagestroemia speciosa in a private garden in the town of Arue, part of the metropolitan area of Papeete in the north of Tahiti. In an attempt to prevent the spread of this pest, the infested tree was treated with broad-spectrum insecticides before it was cut down and destroyed. Homalodisca coagulata was not observed again in Tahiti until JulyAugust 2001, when large populations were detected on numerous plant species in many different places in the metropolitan area of Papeete. The French Polynesian Plant Protection Department was alerted after numerous public complaints about the large quantities of $H$. coagulata excreta raining from infested trees. Two possibilities exist for the discovery of this later infestation: (1) H. coagulata was not eradicated in July 1999, or (2) subsequent accidental introductions led to the 2001 outbreak. These hypotheses are not mutually exclusive and are difficult to distinguish without detailed genetic studies (Davies et al. 1999a,b). It appears most likely that a permanent population of $H$. coagulata was established in Tahiti in 1999 or earlier, probably due to infested ornamental plants bearing egg masses (this life stage is relatively immune to insecticide applications) imported from California.

Since it became established, $H$. coagulata has spread rapidly within the Society Islands. In 2001 it was found in Raiatea (Leeward Islands), in 2002 in Moorea, and small incipient populations of $H$. coagulata were discovered in the Leeward Islands of Huahine and Bora Bora in 2003 and in Tahaa and Maupiti in 2005. At the end of 2004 and the beginning of 2005 , populations of $H$. coagulata were discovered outside the Society Islands in two other archipelagos of French Polynesia substantially distant from Tahiti: the Australs, where two islands were infested (Rurutu and Tubuai) (January 2005, French Polynesian
Department of Agriculture observations), and the Marquesas, where one island was found infested (Nuku Hiva) (November 2004, French Polynesian Department of Agriculture observations). On these recently infested islands, numerous nymphs and adults were found; therefore, the dates mentioned do not correspond to the arrival of H. coagulata but likely indicate that this pest had been present for several weeks or months and was noticed only after populations reached high densities. It is possible that $H$. coagulata is present on other islands in French Polynesia and has not yet been discovered. It is currently unknown if $H$. coagulata has invaded the Tuamotu group.

Continued spread of $H$. coagulata in French Polynesia is probably due to insufficient quarantine measures to prevent unwanted movement between infested and uninfested islands. Movement of plant material is not controlled between islands within the Windward Islands of Tahiti and its close island neighbor Moorea, which explains why $H$. coagulata spread quickly from Tahiti to Moorea. Plants that are shipped from Tahiti to other more distant islands within French Polynesia are required to be dipped in insecticides and fungicides. These dipping treatments are unlikely to kill $H$. coagulata eggs because they are laid under the leaf epidermis (Irvin and Hoddle 2004). However, insecticide residues on leaves could, on contact, kill $H$. coagulata nymphs that emerge from eggs to feed on treated plants. Since September 2004, heightened quarantine measures have been implemented to prevent the movement of infested host plant material from invaded islands into uncontaminated areas. Plants used for propagation are required to be defoliated, treated with insecticides, and fumigated with methyl bromide. Fumigation with methyl bromide is available only in Tahiti. Treated plants are then inspected for H. coagulata eggs and rejected if eggs, nymphs, or adults are found. Flowers and foliage used for decorative displays are inspected for the presence of $H$. coagulata eggs before being moved between islands. If no eggs are found on ornamental flowers and foliage, they are treated with an aerosolized insecticide. If $H$. 


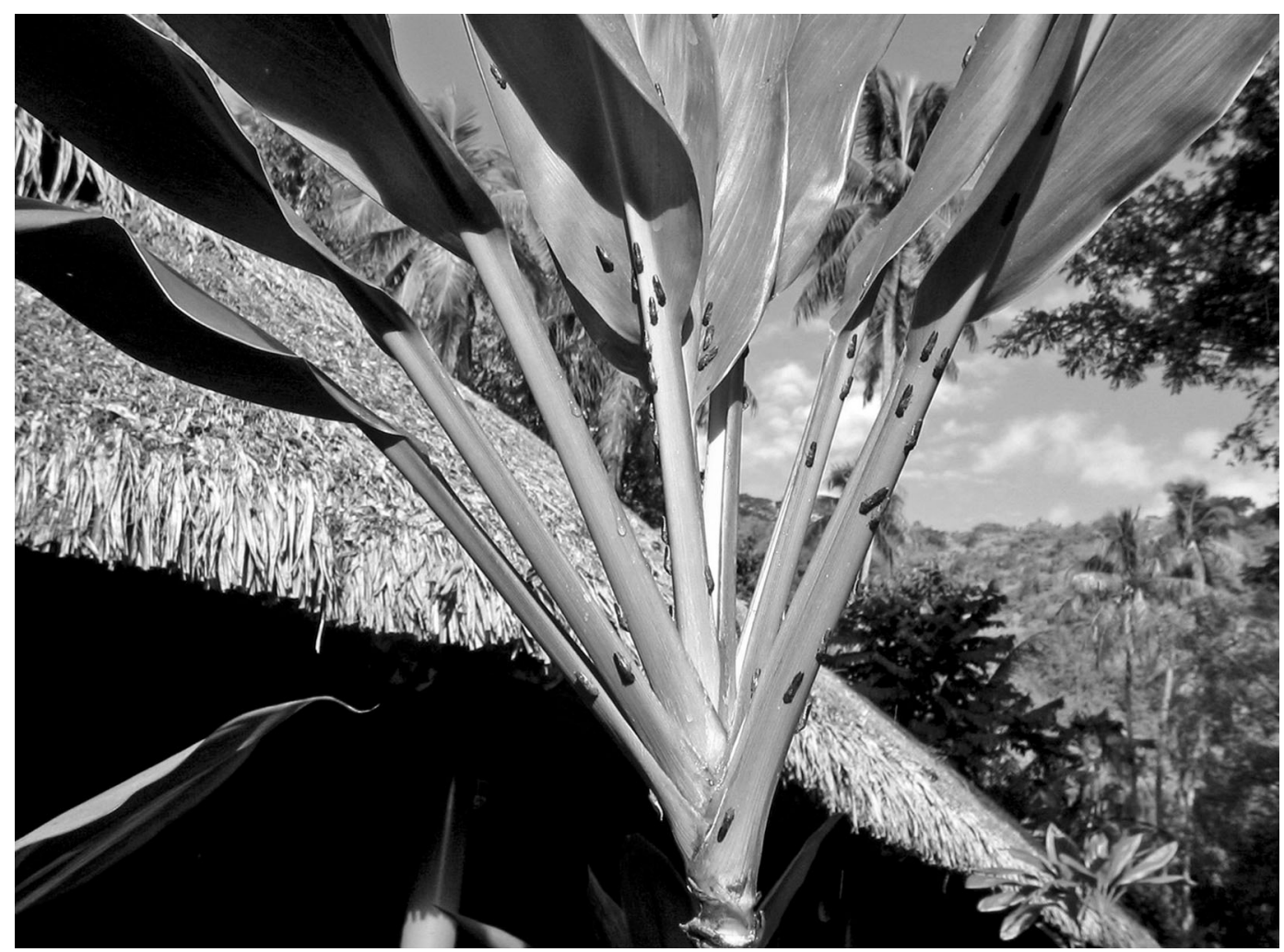

Figure 2. Numerous Homalodisca coagulata adults feeding on Cordyline fruticosa in Paea (Tahiti).

coagulata eggs are found, shipments are rejected or fumigated with methyl bromide. Despite these measures, $H$. coagulata adults or nymphs frequently are found alive inside airplanes that move between islands in French Polynesia or out of French Polynesia to other countries (e.g., New Zealand, Australia, France, and Japan) (M.S.H., J.G., and J.N.P., pers. obs.).

To date, Tahiti and Moorea are the most heavily infested islands, which suggests that Moorea was infested before the nearby island of Raiatea. In these islands, H. coagulata populations have reached densities far exceeding those observed in California or in its native range in the southeastern United States (M.S.H., pers. obs.). Currently in Tahiti and Moorea, large $H$. coagulata populations are readily found feeding and reproducing on a wide variety of exotic and native plants in urban areas at sea level to low-elevation areas (Figure 2). Although apparently less abundant at higher elevations, $H$. coagulata can be found in remnants of undisturbed native habitat on volcanic peaks exceeding $1,400 \mathrm{~m}$ above sea level (Mount Marau, 1,493 m) (J.G., pers. obs.).

\section{FACTORS FAVORING INVASION IN FRENCH POLYNESIA}

The rapid proliferation and spread of H. coagulata in French Polynesia can be explained by five main factors:

(1) The general climate in French Polynesia is ideal for $H$. coagulata reproduction (Hoddle 2004). French Polynesia has a humid tropical climate (latitude $130-150^{\circ} \mathrm{S}$ ), with moderately high year-round temperatures (annual average temperature $20.7^{\circ} \mathrm{C}$ in Rapa 
[Australs] to $27.4^{\circ} \mathrm{C}$ in Takaroa [Marquesas]), high relative humidity (annual average relative humidity $78 \%$ in Takaroa [Marquesas] to $83 \%$ in Rikitea [Tuamotu-Gambier]), and high rainfall (annual average precipitation $1,298 \mathrm{~mm} / \mathrm{yr}$ in Nuku-ataha [Marquesas] to 2,664 mm/yr in Rapa [Australs]) (Laurent et al. 2004). Moderate temperatures and high rainfall ensure ideal year-round breeding conditions for $H$. coagulata. It is estimated that in Tahiti there are six to eight overlapping $H$. coagulata generations a year, compared with two to three generations in California and northern-central Florida (United States).

(2) French Polynesia offers numerous potential exotic and native host plants for $H$. $\mathrm{co}^{-}$ agulata. In French Polynesia plant species are diverse and abundant and provide year-round resources for feeding and egg laying. In particular, high diversity of exotic plants and commonness in urban areas ensure that $H$. coagulata has ideal conditions for feeding and reproduction in areas where it is most likely to be unintentionally moved. In addition to the underside of leaves of trees and shrubs, $H$. coagulata egg masses are commonly found on fern leaves (e.g., Polypodium sp.), grasses, sepals, skins of bananas, and occasionally on the upper surface of leaves.

(3) Our surveys in French Polynesia indicate that there appear to be no effective natural enemies regulating $H$. coagulata populations. Surveys of $H$. coagulata egg masses on Tahiti and Moorea in 2003 indicated very low levels of parasitism: less than $5 \%$ of the egg masses were attacked by parasitoids (Table 1). The parasitoid species reared from $H$. coagulata egg masses was an unidentified platy- gasterid. Female parasitoids attacked only one to three eggs in a typical egg mass of seven to ten eggs. Further, only haploid (male) eggs were oviposited, indicating opportunistic parasitism and that $H$. coagulata eggs were assessed to be of low quality. This absence of effective indigenous natural enemies probably had a direct influence on the establishment and rapid spread of $H$. coagulata in French Polynesia.

(4) The invasion might have been favored by reduction of generalist arthropod predation due to intoxication by $H$. coagulata. Controlled feeding experiments have revealed that some spiders in two species died after predation on $H$. coagulata. Mortality in both the native crab spider Misumenops melloleitao and the pan-Pacific orb-weaving spider Cyrtophora moluccensis appeared to result from lethal intoxication, although no form of chemical defense has been reported in $H$. coagulata. In both spider species, approximately half of all spiders that attacked individual $H$. coagulata nymphs or adults died. Field surveys revealed a decrease in $M$. melloleitao in areas where $H$. coagulata has become common. As H. coagulata populations increase in size and distribution on invaded islands in French Polynesia, this insect will be increasingly encountered by these and other arthropod predators, raising the possibility that declines in populations of susceptible predator species could result (Suttle and Hoddle 2006).

(5) Invasion by $H$. coagulata might have been favored because of weak competition with other insects. Many of the isolated islands in French Polynesia have relatively depauperate arthropod faunas, which implies few competitors for invading insects. In par-

TABLE 1

Homalodisca coagulata Egg Survivorship

\begin{tabular}{llccc}
\hline \hline $\begin{array}{l}\text { No. Eggs } \\
\text { Examined }\end{array}$ & $\begin{array}{c}\text { No. Eggs } \\
\text { Parasitized }\end{array}$ & $\begin{array}{c}\text { No. Eggs } \\
\text { Consumed by } \\
\text { Predators }\end{array}$ & $\begin{array}{c}\text { No. Eggs Killed } \\
\text { by Unidentified } \\
\text { Causes }\end{array}$ & $\begin{array}{c}\text { No. Eggs } \\
\text { Successfully } \\
\text { Hatched }\end{array}$ \\
\hline 2,586 & $32(1.24 \%)$ & $444(17.17 \%)$ & $50(1.93 \%)$ & $2,060(80 \%)$ \\
\hline
\end{tabular}

Note: Data collected by M.S.H. over the period 3-9 September 2003 on Moorea, French Polynesia (246 egg masses were studied; $4 \%$ of collected egg masses were attacked). 
ticular, the cicadellid fauna of French Polynesia seems impoverished, with few known native species and a substantially greater number of exotic species that have established accidentally (Osborn 1934). Consequently, competition by other proconiine cicadellids is nonexistent because this tribe within the Cicadellidae is unique to the Americas and lacks naturally occurring representation in the South Pacific.

Cumulatively, these five major factors (mild climate, abundant year-round host plants for feeding and oviposition, absence of effective natural enemies, intoxication of generalist predators, and weak interspecific competition) have facilitated invasion, a situation that is common for many successful invasive species (Shea and Chesson 2002).

THE THREAT HOMALODISCA COAGULATA POSES TO THE SOUTH PACIFIC

The enormous populations of $H$. coagulata in French Polynesia are cause for concern and urgent remedial actions. Homalodisca coagulata has a well-documented history in the United States of creating major agricultural problems that can result in substantial economic losses (California Department of Food and Agriculture 2004). The most serious threat to crops is a plant pathogenic bacterium, Xylella fastidiosa, that is vectored by $H$. coagulata nymphs and adults. Infection of plants with $X$. fastidiosa blocks the xylem, resulting in a variety of leaf-scorch diseases, which can lead to the death of plants (Hopkins and Purcell 2002). In California, disease is most devastating for grapes, a crop worth approximately US\$5 billion per year (California Department of Food and Agriculture 2004). It is unknown if $X$. fastidiosa is in French Polynesia. However, this bacterium is native to the Americas and it is possible that ornamental and agricultural plants imported to Tahiti from the Americas might be silent reservoirs, harboring bacteria without showing disease symptoms. The establishment of $H$. coagulata with its ability to readily acquire and transmit $X$. fastidiosa could result in disease epidemics affecting native and ornamental plant species and agricultural crops. Of particular concern are native plants, such as Metrosideros, Weinmannia, Dodonea, Glochidion, Hibiscus, and Gardenia, which have no evolutionary association with this pathogen and may be extremely susceptible to infection. In the Americas, the majority of plants that succumb rapidly to $X$. fastidiosa infection are those that have no evolutionary association with the bacterium (e.g., almonds, citrus, European grape varieties, oleander, peaches, and plums). Host plant surveys for $X$. fastidiosa are under way using enzymelinked immunosorbent assay (ELISA) and polymerase chain reaction (PCR) technology, sentinel plant deployment (e.g., periwinkles [Vinca rosea] are highly sensitive to infection with $X$. fastidiosa), and culturing of bacteria from potential host plants to determine if $X$. fastidiosa is present in French Polynesia.

Even in the absence of $X$. fastidiosa, $H$. coagulata at the densities observed in French Polynesia is likely to have a negative impact on the exotic and indigenous flora. The huge quantity of xylem fluid ingested by $H$. coagulata nymphs and adults is suspected to weaken plants by inducing water-stress that leads to leaf yellowing, defoliation, and growth retardation. Physiological disorders caused by populations of $H$. coagulata have been documented. Field studies by Hix (2004) and colleagues have demonstrated that, for orange trees in California, H. coagulata is responsible for changes in carbon and nitrogen metabolism, which is indicative of tree stress, and this pest is responsible for yield losses and reduced fruit size. In a more controlled experiment, Andersen et al. (2003) demonstrated that the quantity of nutrients and water depleted by $H$. coagulata feeding over a 2- to 3week period in Florida (part of the native range in the United States) was substantial but that effects on plant growth and metabolism were negligible. However, experimental conditions used by Andersen et al. (2003) were very different from what is observed in Tahiti and California, where H. coagulata densities are orders of magnitude greater. In addition, in French Polynesia, unlike in Florida and California, high densities of H. coagulata feed continuously all year. Therefore, it is likely that $H$. coagulata has a substantial im- 


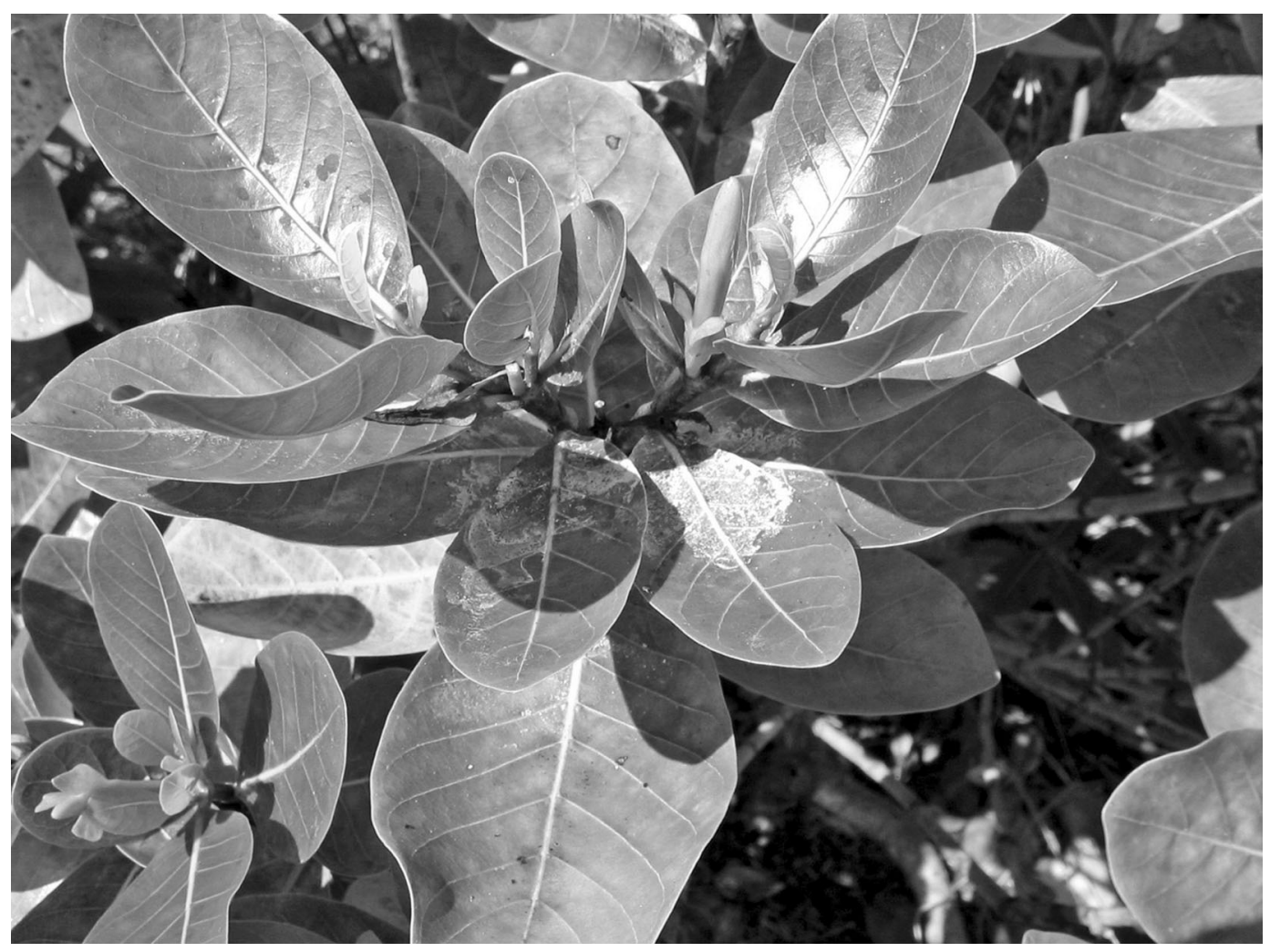

FiguRE 3. Accumulation of "rain" excreted by Homalodisca coagulata nymphs and adults on leaves of Gardenia taitiensis.

pact on plants in French Polynesia, especially in Tahiti and Moorea.

Finally, $H$. coagulata has become a major public nuisance in Tahiti. Excessive excrement produced by nymphs and adults results in "rain," earning $H$. coagulata the common local name mouche pisseuse ("pissing fly"). This "rain" makes it impossible to utilize shade under trees, and vehicles parked under heavily infested trees are drenched in excrement that runs off vehicles and pools on roads and footpaths. Sharpshooter "rain" also creates an aesthetic problem by staining leaves (Figure 3) and fruit. At night, huge numbers of flying $H$. coagulata adults are attracted to lights, invading houses and businesses and causing a considerable nuisance by buzzing around and colliding with people (Figure 4). In some instances, $H$. coagulata adults have been alleged to "bite" people after landing on exposed skin and presumably probing salt glands.

The enormous density of $H$. coagulata in French Polynesia represents an immediate and important threat to other South Pacific nations and trading partners. At particular risk are nations such as New Zealand and Australia with large and important agricultural industries that could suffer immense losses if $H$. coagulata should invade via Tahiti and become established. Recent inspections of cargo bins, hangars, and planes at the international airport in Faaa, Tahiti, found live and dead $H$. coagulata, indicating possible stowaway sites via air transportation (M.S.H., N.D., and G.K.R., unpubl. data). For example, adult $H$. coagulata could easily survive a 5-hr plane flight from Tahiti to New Zealand by flying into cargo holds and later escaping. R.P. has noted reports of live $H$. coagulata 


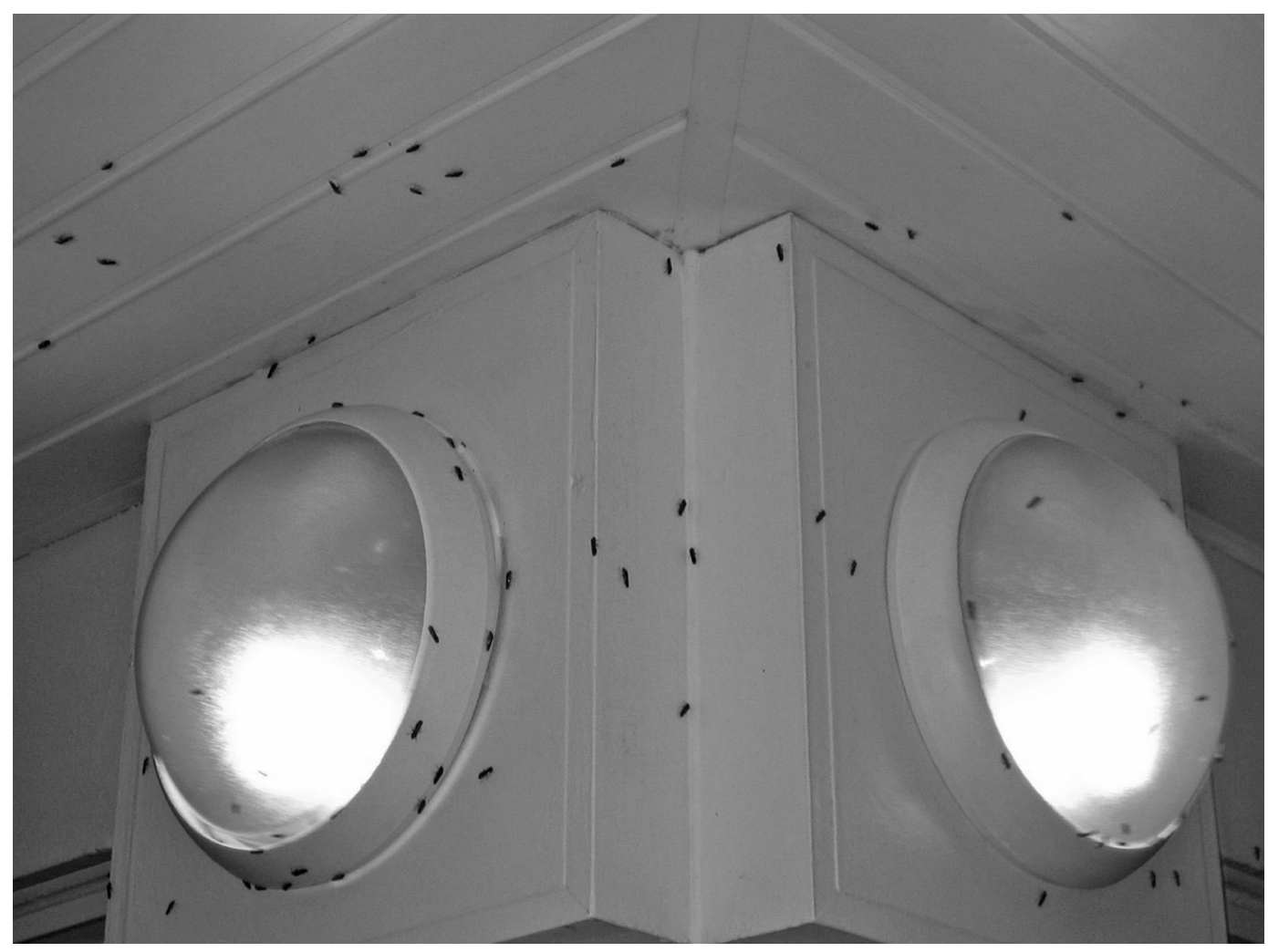

Figure 4. Numerous Homalodisca coagulata attracted to a light at night in Punaauia (Tahiti).

adults being discovered in planes from Tahiti that have landed in Japan. Dead H. coagulata adults, that may have been alive at the beginning of transit, have been found in planes arriving in Cairns, Australia, that departed from Tahiti and passed through New Caledonia (M. Fletcher, 2005, pers. comm.). It is likely that the $H$. coagulata that invaded Easter Island came from Tahiti.

\section{BIOLOGICAL CONTROL OF HOMALODISCA COAGULATA}

Consequently, there is an urgent and immediate need to control high-density populations of $H$. coagulata in French Polynesia. By reducing population densities many problems, both actual (human nuisance, and continued range expansion) and potential (widespread vectoring of $X$. fasitidiosa), would be miti- gated. A review of potential control options was commissioned in 2003 by the French Polynesian Ministry of Agriculture. An alliance between University of California (Berkeley and Riverside Campuses), the University of California Richard B. Gump South Pacific Research Station on Moorea, and the French Polynesian Agricultural Research and Plant Protection Departments has guided the development of the classical biological control program against H. coagulata. In 2004, the biological control program using an egg parasitoid, Gonatocerus ashmeadi (Hymenoptera: Mymaridae) (Figure 5), commenced when populations of this parasitoid were established in a quarantine facility at Papara (Tahiti). Gonatocerus ashmeadi is the most effective natural enemy attacking $H$. coagulata in California, hence its selection for this project. A second egg parasitoid, G. triguttatus, 


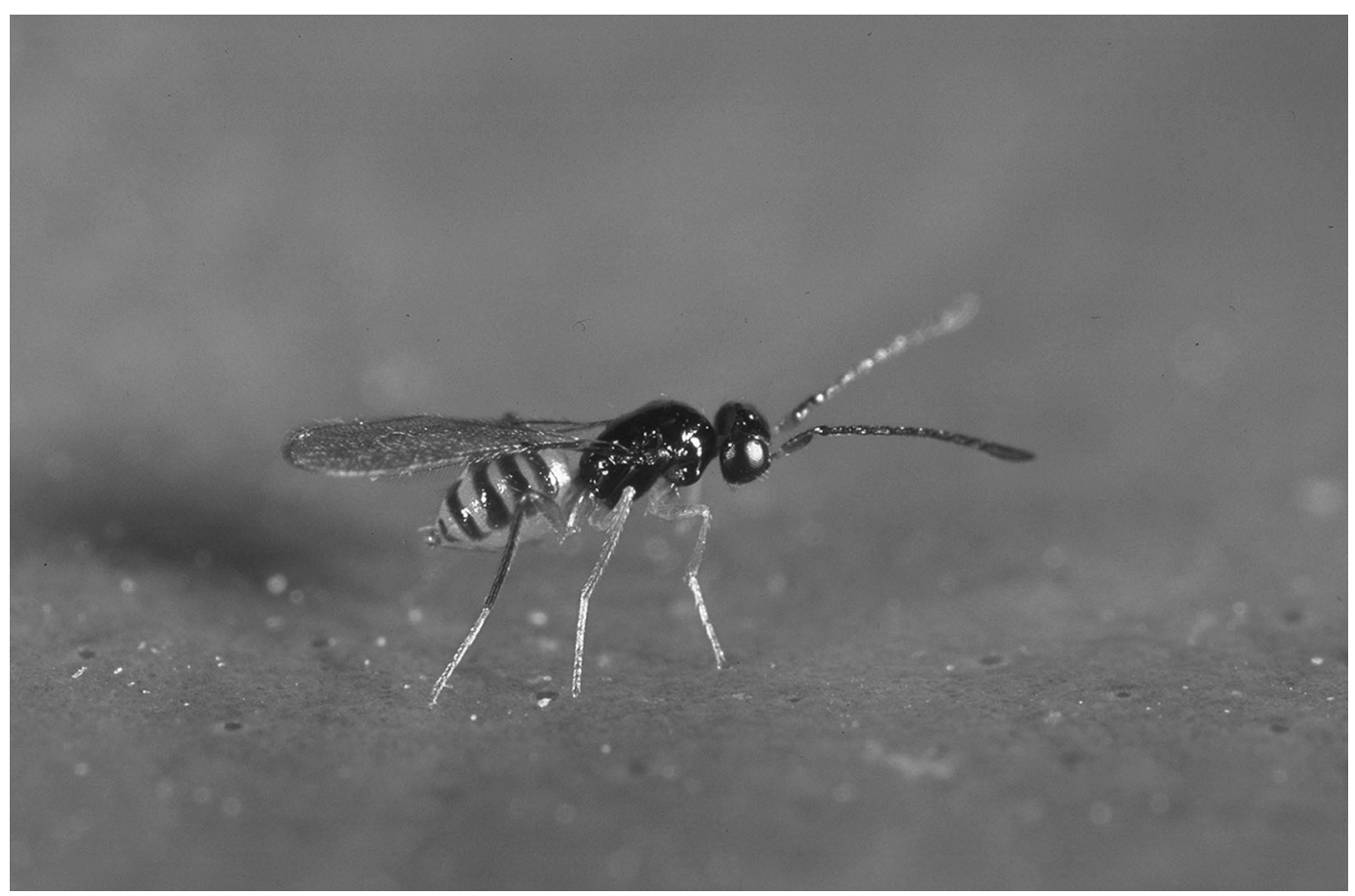

FIGURE 5. Gonatocerus ashmeadi, an egg parasitoid of Homalodisca coagulata. Photo by Jack Kelley Clark, courtesy UC Statewide IPM Program.

may also be considered for release in French Polynesia, but release of $G$. triguttatus will depend on the level of population suppression achieved by G. ashmeadi.

A major requirement for classical biological control of H. coagulata in French Polynesia is consideration of environmental safety (i.e., minimizing potential nontarget impacts on native cicadellid species). Particular attention is being paid to the identification and quantification of risk to native nontarget fauna before the introduction of exotic parasitoids commences. Currently, host risk assessment evaluations and native cicadellid surveys are under way to provide empirical data on the likelihood and magnitude of nontarget impacts. Ultimately, the decision to release exotic parasitoids for biological control of $H$. coagulata rests with the French Polynesian government. The regulatory authorities must use a scientific approach to weigh the ecological, economic, and social risks of con- tinued spread of $H$. coagulata against the potential conservation threat of introducing exotic parasitoids to French Polynesia. Scientific data will be paramount in guiding the decision to release exotic parasitoids for H. $\mathrm{co}^{-}$ agulata control. Carefully designed studies will identify potential environmental hazards and reduce uncertainties pertaining to unintentional nontarget impacts and levels of expected control to be achieved by natural enemies of $H$. coagulata.

\section{ACKNOWLEDGMENTS}

We thank the University of California Regents for the use of $H$. coagulata and G. ashmeadi and G. triguttatus photographs.

\section{Literature Cited}

Andersen, P., B. Brodbeck, and R. Mizell. 2003. Plant and insect characteristics in re- 
sponse to increasing density of Homalodisca coagulata on three host species: A quantification of assimilate extraction. Entomol. Exp. Appl. 107:57-68.

Brodbeck, B. V., R. F. Mizell, and P. C. Andersen. 1993. Physiological and behavioural adaptations of three species of leafhoppers in response to the dilute nutrient content of xylem fluid. J. Insect Physiol. 39:73-81.

California Department of Food and Agriculture. 2004. Pierce's Disease control program. Report to the legislature, February 2004.

Davies, N., F. X. Villablanca, and G. K. Roderick. 1999a. Bioinvasions of the medfly, Ceratitis capitata: Determining sources using DNA sequences at multiple intron loci. Genetics 153:351-360.

- 1999b. Determining the source of newly founded populations: Multilocus genotyping in nonequilibrium population genetics. Trends Ecol. Evol. 14:17-21.

Hix, R. L. 2004. Glassy-winged sharpshooter impact on orange yield, fruit size, and quality. Pages 11-14 in Proceedings of the 2004 Pierce's Disease Research Symposium, 7-10 December 2004. Copeland Printing, Sacramento, California.

Hoddle, M. S. 2004. The potential adventive geographic range of glassy-winged sharpshooter, Homalodisca coagulata, and the grape pathogen Xylella fastidiosa: Implications for California and other grape growing regions of the world. Crop Prot. 23:691-699.

Hoddle, M. S., S. V. Triapitsyn, and D. J. W. Morgan. 2003. Distribution and plant association records for Homalodisca coagulata (Hemiptera: Cicadellidae) in Florida. Fla. Entomol. 86:89-91.

Hoover, W. 2004. New invader may threaten crops. Honolulu Advertiser, 14 May 2004.

Hopkins, D. L., and A. H. Purcell. 2002. Xylella fastidiosa: Cause of Pierce's Disease of grapevine and other emergent diseases. Plant Dis. 86:1056-1066.

Irvin, N. A., and M. S. Hoddle. 2004. Oviposition preference of Homalodisca coagulata for two Citrus limon cultivars and influence of host plant on parasitism by Gonatocerus ashmeadi and G. triguttatus (Hymenoptera: Mymaridae). Fla. Entomol. 87:504-510.

Laurent, V., K. Maamaatuaiahutapu, J. Maiau, and P. Varney. 2004. Atlas climatologique de la Polynésie française. Météo France, Direction Interrégionale de la Polynésie française.

Osborn, H. 1934. Cicadellidae from the Society Islands. Bernice P. Bishop Mus. Bull. 113:115-118.

Pilkington, L. J., N. A. Irvin, E. A. Boyd, M. S. Hoddle, S. Triapitsyn, B. G. Carey, W. A. Jones, and D. J. W. Morgan. 2005. Biological control of glassy-winged sharpshooter in California. Calif. Agric. 59 (4): 223-228.

Raven, J. A. 1983. Phytophages of xylem and phloem: A comparison of animal and plant sap-feeders. Adv. Ecol. Res. 13:135234.

Secretariat of the Pacific Community. 2002. Incursion of glassy-winged sharpshooter Homalodisca coagulata in French Polynesia. Pest Alert, Plant Protection Service. http://www.spc.org.nc/pps/PestAlerts/ PestAlertNo24.pdf (accessed June 2005).

Shea, K., and P. Chesson. 2002. Community ecology theory as a framework for biological invasions. Trends Ecol. Evol. 17:170176.

Sorensen, J. T., and R. J. Gill. 1996. A range extension of Homalodisca coagulata (Say) (Hemiptera: Clypeorrhyncha: Cicadellidae) to southern California. Pan-Pac. Entomol. 72:160-161.

Suttle, K. B., and M. S. Hoddle. 2006. Engineering enemy-free space: An invasive pest that kills its predators. Biol. Invas. (in press).

Triapitsyn, S. V., and P. A. Phillips. 2000. First record of Gonatocerus triguttatus (Hymenoptera: Mymaridae) from eggs of Homalodisca coagulata (Homoptera: Cicadellidae) with notes on the distribution of the host. Fla. Entomol. 83:200-203.

Wells, J. M., B. C. Raju, H. Y. Hung, W. G. Weisburg, L. M. Parl, and D. Beemer. 1987. Xylella fastidiosa gen. nov. sp. nov.: Gram-negative, xylem-limited, fastidious plant bacteria related to Xanthomonas spp. Int. J. Syst. Bacteriol. 37:136-143. 